\title{
The Quebec Cooperative Study of Friedreich's Ataxia: 1974-1984 - 10 Years of Research
}

\author{
A. Barbeau
}

\begin{abstract}
In this paper the author reviews the progress accomplished in the understanding of Friedreich's disease since the start of the "Quebec Cooperative Study of Friedreich's Ataxia" in 1974. The last ten years have indeed seen important strides taken in the definition and nosography of the hereditary ataxias and the characterization of a number of new entities. Biochemically, the principal leads uncovered during the initial prospective survey, have been pursued to great detail. Unfortunately no clear-cut constant and severe enzyme block in the principal metabolic pathways has yet been identified, despite intensive studies. It is postulated that the defect may instead be a regulatory one and involve a decreased availability or utilization of one of the vitamin cofactors that are known experimentally, or clinically, to produce central nervous system damage with ataxia: Vitamin E, Biotin or Pantothenic Acid. Studies in that direction and in molecular genetics to localize the Friedreich's disease gene are being untertaken for the next phase of the Cooperative Study.
\end{abstract}

RÉSUMÉ: Dans le présent article l'auteur passe en revue le progrès enregistré dans la compréhension de la maladie de Friedreich depuis le début de l'Etude Coopérative du Québec, en 1974. Ces dernières dix années ont été marquées par une évolution importante dans la définition et la classification des ataxies héréditaires et la caractérisation de plusieurs nouvelles entités. Biochimiquement nous avons investigué en grand détail les principaux indices mis en lumière lors de l'étude prospective initiale. Malheureusement nous n'avons pas trouvé de bloc enzymatique évident, constant et sévère, comme celui qui a permis d'élucider la maladie de Refsum. Nous proposons que le défaut dans la maladie de Friedreich se situe plutôt au niveau de la disponibilité ou de l'utilisation d'une des vitamines (co-facteurs) connues pour causer expérimentalement, ou cliniquement, des lésions du système nerveux, surtout sensitif, avec ataxie: il s'agit de la vitamine E, de la biotine ou de l'acide pantothénique. Nous avons entrepris des études dans ce sens ainsi qu'une investigation, par des méthodes de génétique moléculaire, du site de localisation chromosomique du gène de la maladie.

Can. J. Neurol. Sci. 1984; 11:646-660

In November 1974, Claude Saint-Jean (see I-1*), despite his severe handicap, courageously founded " L'Association Canadienne de l'Ataxie de Friedreich" and immediately decided that all the monies raised would be spent on research into the cause and treatment of Friedreich's disease and allied disorders. When he asked the author in 1975 to form a Scientific Advisory Board to direct that research, Claude Saint-Jean also gave us a challenge and a goal: to find the cause of Friedreich's disease within 10 years. We are now entering the 10 th year of this investigation (the Quebec Cooperative Study of Friedreich's Ataxia or QCSFA) and, unfortunately, we cannot yet state that we clearly know what causes the disease, but we have taken important strides in that direction. It is the purpose of the present paper to review the progress made and to outline the approaches that should be followed in the next few years to reach that goal.

\section{Philosophy and Plan of the Investigation}

The Scientific Committee in 1975 made a series of decisions which, at the time, were considered innovative, if not revolutionary. In contrast to almost all other disease-related Foundations, the grant or award system was forfeited in favour of orientations in research formulated by a Scientific Advisory Board and contracts for specific investigations negotiated by the Scientific Director with researchers chosen for their particular expertise in the desired field. These contracts were for a finite period and to answer a definite question. No promise of renewal or continued support was made beyond the original purpose, thus many researchers were involved in the Cooperative Study only for a short period, but their contribution was always important. The answers obtained in this way, whether positive or negative, helped in completing the mosaic of knowledge on Friedreich's disease which we were patiently building. 
Another decision made early in this program was to involve multidisciplinary teams from each of the four Medical Schools in the Province of Quebec. This was to simultaneously stimulate competition and foster cooperation in a way that permitted the verification of findings by different teams and different laboratories. Voluntary duplication was programmed into the protocole, preferably with different methodologies. Later, laboratories from other countries were also recruted, particularly from other continents. Finally, taking heed of human nature, we opted to avoid conflicts of priority between our numerous contributors by ruling that publications, refereed and edited by the Scientific Board and by outside consultants, would always appear at the same time as all the others. Thus special regular (12-18 months) supplements to the Canadian Journal of Neurological Sciences were used as results were compiled instead of random publications in various journals. In addition, each fall, we gathered all our active researchers and some out side consultants for a three day scientific retreat with no formal presentations, but long animated discussions on the significance of recent findings from our Cooperative Study Group or from other laboratories. Plans and protocoles for the following year were elaborated at that time. Unproductive lines of investigation were dropped in favour of more promising ones.

A final point is of importance: as much as was feasible, the same patients identified in the initial elaboration of the diagnostic criteria and in the homogeneity tests were used time and time again for all the biochemical studies. This permitted correlation of different findings and also gave a picture of disease evolutionary changes.

From such a philosophy, a 5 phase program of action was elaborated (Table 1): it was first decided to carry out a complete prospective study (clinical and biochemical) of some 50 cases of Friedreich's disease to search for clues to any biochemical abnormality and to define strict diagnostic criteria for the disorder. To this purpose a systematic survey of all metabolic pathways was carried out. The second phase was to involve detailed biochemical investigation of the clues thus uncovered and to sort out secondary manifestations of the disease from possible etiologic leads. From the array of biochemical modifications observed, it was the role of the third phase to explain the pathophysiology of the various symptoms previously defined and to outline the final paths of investigation towards the cause. This is approximately where we now stand, as seen in the present special issue. The next phase of this research will involve, we hope, the identification and characterization of the basic defect and the localization on a specific chromosome of the site of the gene mutation. Finally, phase 5 will carry out experimental therapeutic approaches, preferably in a double blind fashion and will concentrate on possible preventive measures.

\section{State of Art In 1974}

Before analyzing the possible progress accomplished over the last ten years by members of the Quebec Cooperative Study and by outside laboratories, it is useful to take stock of the comprehension of Friedreich's disease as it was in 1974, our starting point. Luckily four papers published at about that time reviewed the situation: the clinical features were detailed by

\footnotetext{
* For references to QCSFA papers, see note in Reference section. All other references cited as usual.
}

Table 1: Research on Friedreich's Disease 1974-1984

\section{PLAN OF INVESTIGATION}

PHASE 1

\author{
A PROSPECTIVE SURVEY \\ Part One: Literature Review \\ Part Two: Preparation of Protocole \\ Part Three: Screening Procedure \\ Part Four: Collating Results (1976)
}

PHASE 2 BIOCHEMICAL INVESTIGATIONS

Part One: Clinical and Biochemical Studies (1978)

Part Two: Further Clinical and Biochemical Studies (1979)

PHASE 3 CliniCAL PATHOPHYSIOLOGY

Part One: Clinical Pathophysiology (1980)

Part Two: Enzymology and Clinical Trials (1982)

Part Three: Further Clinical and Biochemical Studies (1984)

PHASE 4 ETIOLOGY AND MOLECULAR GENETICS

Part One: Identifying the basic defect

Part Two: Gene Localization

PHASE 5 TREATMENT AND PREVENTION

Part One: Experimental Therapeutics

Part Two: Therapeutic Trials

(---) date of publication of results

Tyrer (1975) in the Handbook of Neurology; the biochemistry by Lubozynski and Roelofs (1975); the pathology by Hughes et al. (1968), and the electrophysiology by McLeod (1970). What did we know? Not much. The clinical definition of Friedreich's disease as given by Tyrer (1975) is little ahead of the original description (I-2).* It is vague and encompasses dominant and sporadic cases as well as recessively inherited ones, cases with increased tendon reflexes and others without, cases associated in the same kindreds (albeit as "formes frustes" or "formes atypiques de passage") with a bewildering assortment of other disorders, and intermediate forms with olivo-ponto-cerebellar atrophy, extrapyramidal syndromes, myoclonia, neurogenic muscle atrophy, myopathies and polyneuropathies! The review, except where it concerns pes cavus and scoliosis, is only a compedium of previous opinions by many authors, and not a statement of the author's personal views on the subject. The place of Friedreich's disease within hereditary ataxias is not well defined.

The biochemistry of Friedreich's disease was essentially non existant in 1975 (Lubozynski and Roelofs, 1975) except for the 
recognition of the high prevalence of diabetes. Patient investigations by Robinson and his collaborators had probably accumulated most of our knowledge on tissue enzymes, lipids and amino acids in Friedreich's disease (Robinson, 1966 a, b; 1968 ; Robinson et al., $1965 \mathrm{a}$, b). The most significant finding was probably the demonstration, thought to be secondary because not specific, that concentrations of aspartic acid, glutamic acid and leucine were decreased in affected white matter of the spinal cord (Robinson, 1968). Mostly forgotten were KrausRuppert's suggestion (1964) that the changes resulted from "premature degeneration of the enzymes controlling the oxidative processes in the cell" and the observation by Szanto and Gallyas (1966) that red blood cell average life span was decreased in Friedreich's disease. These findings will be recalled later.

The pathology of Friedreich's disease was well defined by 1975. In fact, the most extensive study still known was published by Hughes et al. in 1968 on 18 cases of the disease. The following characteristic changes in the spjnal cord were found to be invariably present: degeneration of the posterior columns, spino-cerebellar tracts and pyramidal tracts. In the peripheral sensory pathway these authors found extensive neuronal degeneration, especially involving the large neuron cell bodies in the posterior root ganglia and of the central and peripheral large myelinated axons from these cell bodies, with preservation of the fine unmyelinated nerve fibers in the posterior spinal nerve roots and the peripheral sensory nerves. Dyck and Lambert (1968) also described a selective degeneration of the dorsal root ganglion cells and of large, myelinated fibers.

Finally, the state of electrophysiologic investigations at the start of our study is best summarized in the paper by McLeod (1970). The major finding is a marked reduction or absence of sensory action potentials in median and sural nerves. This was confirmed by Dunn (1973). Cardiac anomalies were also investigated and reviewed by Hewer (1968, 1969), by Boyer et al. (1962) and by Thorén (1964).

\section{Clinical Contributions From the OCSFA (1975-1984)}

As noted above, the first task of the Cooperative Study was to carry out a survey of the situation of hereditary ataxia in the Province of Quebec. This survey was summarized by Barbeau (Barbeau, 1980). Over the years special attention was paid to specific disorders, some never before described, such as ataxic erythrokeratodermia (Giroux and Barbeau, 1972; Barbeau and Giroux, 1972), and the autosomal recessive spastic ataxia of Charlevoix-Saguenay (ARSACS) for which extensive clinical (II-2), electrophysiological (III-6, 7, 8, 10) and radiological (III-9) investigations were carried out; some better defined through the study of geographic and genetic isolates: olivoponto-cerebellar degeneration (II-4) and Machado-Joseph disease (VI-3); or through extensive investigations of a few rare cases: familial periodic ataxia (VI-7) and lysosomal deficiencies (VI-17).

From the results of such a survey, attempts were made to put some order into the confusing issue of classification of hereditary ataxias. A pilot study (V-I) on recessive ataxias led eventually to a new classification scheme which is easily coded for use with personal computers (VI-1) and which will now be submitted for discussion and possible adoption by the International Research Group on Hereditary Ataxias of the World Federation of Neurology. Concommittent with these efforts, a scoring and staging system for the ataxias was developed by members of the group (IV-1, 3) and submitted to a number of successful field tests (IV-1; VI-3, 4). Simultaneously, objective evaluation schemes utilizing sophisticated physical measurements were developped and tested in double-blind assays of experimental therapeutic approaches (II-19; IV-5; V-9, 10, 11, 12, 13; VI-8).

The most important clinical development occurred early and was essential to all the biochemical studies subsequently carried out. This is the strict and clear definition of "typical Friedreich's disease" (I-3) and the outlining of criteria to be used for its diagnosis (I-2; II-1). This "must" step in the description of the disease has permitted definitive characterization of its genetics: it is now universally recognized that typical Friedreich's disease is always inherited as an autosomal recessive trait (I-4). The fact that other transmission modes appear to be present in families with some but not all the obligatory clinical features of "typical" Friedreich's ataxia did not deter from our conclusion, but in fact permitted the delineation of new genetic entities (VI-6) and the differentiation from previously described ones, like Charcot-Marie-Tooth (V-2) and the so-called RoussyLevy Syndrome (VI-5).

The same criteria were useful in carrying out the genetic and genealogical studies of isolated clusters (III-11) of hereditary ataxia, and in identifying the common origin of most cases of Friedreich's ataxia in the French Canadian population (I-5; VI-2). This commonality in origin is an extremely important point when studying the genetic background of the patients on whom we carried out our biochemical studies. It can now be stated that French Canadian Friedreich's disease cases are homogenous and that they are essentially similar to cases of the same disease in Italy, Spain, France and South America (IV-34; V-2, 14; VI-6) despite claims to the contrary. Whether they are similar to cases of Friedreich's disease in Great Britain and the U.S.A. must still be verified.

The homogeneity in clinical presentation of "typical" Friedreich's disease in French Canadians is such that it led, because of some small but constant differences, to the recognition of two variant disorders in French-speaking patients of Acadian origin. The first is associated with severe familial amyotrophy (IV-2), the second with a slower evolution form of areflexic recessive ataxia (VI-4). The same clinical picture was found in "Cajuns" of Louisiana, 200 years after their separation from the area of origin in Acadia (VI-4).

After the delineation of strict diagnostic criteria for Friedreich's disease, the efforts of the Cooperative Study Group were directed to the electrophysiological and pathological characterization of these patients and to the analysis of specific symptomatic components. It was thus demonstrated that the clinical and genetic homogeneity of our patients was also present at postmortem, whether for the heart (I-15; IV-8), the dorsal root ganglia (V-8) or the brain (III-5; VI-16). French Canadian patients, in this respect at least, are similar to the cases reported from Great Britain (Hewer, 1968, 1968; Hughes et al., 1968; III-5). Studies with standard electroencephalography $(\mathrm{I}-4,7)$, electromyography and nerve conductions (I-8) and electronystagmography (II-3; VI-II) confirmed and extended findings from the literature cited above. Thus it was shown that sensory evoked potentials were absent or markedly decreased in the sural nerve of all typical patients, even early in the disease or before the appearance of ataxic symptoms (V-29). This crucial observation indicates that, whatever the biochemical defect causing Friedreich's disease, it must exert its deleterious effects extremely 
early in the developmental period (before age 3), at least upon the posterior columns, dorsal root ganglia and large myelinated sensory fibers. Later studies and observations (V-29) delineated other fragile periods in the progression pattern of Friedreich's disease: puberty with rapid body growth and episodes of fever or of malnutrition. Interestingly during these episodes both scoliosis and vibration sense decreases can act as markers of the progression. Determinants of an earlier death and of more severe disease evolution have been identified ( $V-29)$, mainly as the presence of clinical diabetes and that of a decompensated hypertrophic cardiomyopathy.

While absent sensory action potentials, in the lower limbs particularly, are early signs of the illness and vary little with progression of the disease, other evoked potentials, on the other hand, can be used as markers of progression in severity and extent. Visual potentials (III-4; VI-10), and brain stem auditory potentials (V-7) can be used with reliability to measure the spatial progression, and appear to be abnormal only after a few years of the illness (Jabbari et al., 1983) although the processing is normal (Cacace et al., 1983). Their presence cannot, however, guide us towards the basic cause of Friedreich's disease.

Similarly, the Cooperative Study Group expanded much effort in the functional analysis of individual symptoms. Perhaps the best examples of this are the numerous studies on the form. extent, diagnosis and progression of the cardiomyopathy. Clinical signs and symptoms were first investigated in the initial group of typical patients (I-9), then the use of electrocardiography and vectocardiography (I-10), of echocardiography (I-11), of angiography and hemodynamics (1-12,13) and of thallium (VI-15) were evaluated as diagnostic tools. It was shown that a combination of tests (preferably ECG + Vecto + Echo) must be used to demonstrate the hypertrophic cardiomyopathy which is found present in nearly all cases. The symmetric or asymmetric nature of this hypertrophy was also debated clinically (IV-6) and pathologically (I-15; IV-8). Finally the presence of a similar cardiomyopathy was excluded in obligate heterozygotes and other relatives by some (III-1) but not by others (I-4). The evolution of this cardiomyopathy was equally studied (III-2). Pulmonary function also received special attention, particularly with the view of delimiting its contribution to the progression of the disease (I-14; II-7) and the regulation of respiration (III-3). Urodynamic evaluations were also reported (V-6).

Finally, the pathophysiology of scoliosis and of pes cavus were explored in detail. New instruments were designed to position the patients for the X-Ray study of scoliosis (IV-7; V-3; VI-14) and the evaluation of its natural history. In this way it was demonstrated that between the ages of 10 and 15 years, there was a substantial increase in the Cobb angle values. Associated with this sudden increase in the Cobb measurements was a relative torsion between the thoracic and lumbar segments. A computer program generating a tri-dimensional display of the spine from the standardized radiographs was developed. Similar investigations of the pes cavus deformity and kinematics were also undertaken (V 4, 5; VI-12, 13).

To investigate in more detail the pathophysiology and the biochemistry of inherited ataxias it is necessary to develop animal models. The Cooperative Study Group did not neglect this aspect. Indeed the various models analyzed over the years were: 3-acetylpyridine injections in rats which produced a degeneration of the cerebellar climbing fibers and changes in the concentration of various amino acids (II-14;III-12;IV-2I; V-15); thiamine deficiency in the rat (III-13); acrylamide injections in the rats which produce a peripheral neuropathy, mainly affecting the hind limbs $(\mathrm{V}-16,17)$ and finally, as a model of the cardiac hypertrophy and the effect of taurine feeding upon this anomaly: the Syrian golden hamster (II-5: III-14; IV-18). Diabetes was investigated with the Alloxan model (II-15). Recently a new mouse model called "dystonia musculorum" was described which showed ataxic dystonic postures reminiscent of advanced Friedreich's and biochemical changes in glutamate and GABA similar to those reported in humans with Friedreich's disease $(\mathrm{V}-18)$. This mouse model is the most promising one yet found, particularly since it is now known that aspartate is the likely neurotransmitter in cerebellar climbing fibers (Wiklund et al. 1982).

\section{Biochemical Contribution From the QCSFA (1975-1984)}

The systematic biochemical survey which we carried out during the first phase of the Study presented us with five main findings to be investigated (1-21):

(1) A defect in glucose and insulin metabolism

(2) A defect in pyruvate metabolism

(3) A defect in the transport or handling of certain amino acids

(4) A mild defect in lipids and lipoproteins (decreased plasma cholesterol and decreased B-lipoproteins)

(5) A defect in hepatic cell function, particularly in bilirubin metabolism

Further studies were undertaken to explore the significance of each of these possible disturbances (IV-13; V-25).

\section{(a) Glucose Metabolism}

As stated previously, the only facts on the biochemistry of Friedreich's disease known in 1975, at the start of the Cooperative Study, were the increased prevalence of diabetes (Podolsky et al., 1964) and the decrease in spinal cord glutamic and aspartic acids (Robinson, 1968). As planned in the protocole ( $1-1$ and above), we first carried out a systematic survey of most metabolic pathways (I-16) which confirmed the increased prevalence of clinical and chemical diabetes (circa 40\%) in Friedreich's disease, as well as a frequently abnormal insulin response (increased) to a glucose load (I-17). Further studies were carried out in obligatory heterozygotes and relatives and again indicated an increased incidence of glucose intolerance (III-16; IV $-9,10)$. Insulin binding to erythrocytes was slightly abnormal among diabetic Friedreich's disease patients but normal in the non-diabetic ataxic group. Similarly, glycosylated hemoglobins are abnormal only in diabetic ataxic patients (IV-11). Finally, insulin resistance was shown to correlate well with the duration of neurological symptoms and appears to reflect the degree of immobility (VI-23). An insulin receptor defect in circulating monocytes isolated from these patients was also demonstrated (VI-23). At the present time, the anomalies relating to the presence of diabetes: an abnormal glucose tolerance curve and hyperinsulinemia under the same circumstances, appear to be due respectively to a slow down in glucose transport across cell or mitochondrial membranes and to a receptor defect for insulin on these membranes.

\section{(b) Pyruvate Metabolism}

Based on the above observations, the first finding of importance was the abnormal response of pyruvate and lactate noted after a glucose load in patients with Friedreich's disease (Barbeau, 
1975; 1-20). This led to a great number of investigations in our laboratories and in many other centers and has been the focus of attention since 1975, with oscillating fervour. At the same time, Kark and co-workers (1974) were outlining a possible deficiency in muscle pyruvate dehydrogenase (PDH) and particularly in its third component lipo-amide dehydrogenase (LAD) (Blass et al, 1976; Kark et al., 1979 a, b). Most of our own studies were summarized in 1980 (IV-22). In short, after investigating the kinetics of the enzyme complexes in question (II-10), we were able to show essentially normal values for $P D H$ in platelets (I-20; II-10; IV-14), and in fibroblasts (II-11; III-17; IV-12), but decreases in serum LAD (1-20; 11-10; IV-13). It is interesting that the slight kinetic defects noted in serum LAD were abolished after treatment with Lecithin (phosphatidyl choline) (IV-13) favouring a still unknown substrate deficiency. Other authors not connected with the Cooperative Study were also unable to confirm the specificity of muscle and fibroblasts changes in PDH or LAD (Evans, 1980; Stumpf and Parks, 1978, 1979). We can summarize the current status of the problem by stating that all the evidence indicates that the in vivo oxidation of pyruvate is slow in Friedreich's disease, but that this is not specific. These facts also indicate that the primary genetic defect is not to be found in the PDH/LAD complex per se, but that in Friedreich's disease the smooth interaction between these components may be abnormally regulated, possibly even under genetic control, by a factor or factors operating in blood or cell membranes, or both (see infra for further details). The $30-40 \%$ decrease in serum LAD activity values were also found reflected in the activities of other important complexes where this third component is essential: alpha-keto-glutarate dehydrogenase (Kark et al., 1974) and valine dehydrogenase (V-27, 28). In neither case was the deficiency of a sufficient magnitude to be called primary

The focus of research centered upon Krebs cycle enzymes and energy production (IV-22) as being responsible for most of the symptoms of Friedreich's disease was also taken up by other laboratories and researchers who found defects in other steps of this fuel utilizing system. Thus,intermittent ataxia was found after multiple carboxylase deficiencies (Sander et al, 1980, 1982; Thoene and Wolf, 1983). Dijkstra and co-workers (Dijkstra et al. 1983) even demonstrated an important decrease in the activity of pyruvate carboxylase in Friedreich's disease. This finding has not yet received the attention it deserves, nor has it been duplicated by others.

Similarly, our finding that glutamate and aspartate were apparently deficient in the brain (III-20), spinal cord (Robinson, 1968; Butterworth and Giguère, 1982), and heart (VI-20) of patients with the disease, probably secondarily to specific nerve fiber damage (Wiklund et al., 1982) because this decrease was not present elsewhere (VI-18), was duplicated in certain forms of olivo-ponto-cerebellar atrophy (Perry et al., 1978) and in many animal models of hereditary ataxia (II 14; III-12, 13; V-18). We were even able to show that intra-ventricular injections of glutamate and aspartate could reverse the sign of ataxia in rats (IV-21). Nevertheless glutamate transport in fibroblasts was found normal in Friedreich's disease (III-22). These results led to the investigation of glutamate dehydrogenase (GDH), the enzyme that catalyses the formation of glutamate. GDH concentrations in Friedreich's disease were slightly decreased (IV-15), possibly through a substrate deficiency, but not to the extent found in certain forms of recessive olivo-ponto-cerebellar ataxias by Plaitakis and others (Plaitakis et al., 1980 a, b, 1981, 1982, 1983, 1984; Chokroverty et al., 1983; Duvoisin et al. 1983; Yamaguchi et al., 1982). Our findings in Friedreich's disease were confirmed by others (Filla et al., 1984). Recently Plaitakis et al. (1984) demonstrated that in the recessive OPCA patients the leukocyte GDH decrease in activity was limited to the "particulate-heat labile" component, the "particulate heatstable" component being normal. Like other "ataxic multisystem degenerations" this entity is clearly different from Friedreich's ataxia, even if it shares its recessive mode of transmission.

The most important development in the field of energy supply in Friedreich's disease was published by Stumpf and his group (Stumpf et al., 1982; Stumpf 1982; Stumpf et al., 1983). In such patients these authors reported a $90 \%$ decrease in the fibroblast activity of mitochondrial malic enzyme. They considered that this could be the primary defect, particularly in view of the importance of malic enzyme in the heart (Stumpf, 1982), and the fact that they found intermediate values in heterozygotes (Stumpf et al., 1983). Most of these conclusions were corroborated by Bottachi and Di Donato (1983) who reported low values of the NADP -linked mitochondrial malic enzyme in muscles, but at a level about $35 \%$ that of controls. Unfortunately, our own investigations could not confirm the original results in fibroblasts (VI-26) or in the heart (VI-27). Unless methodological differences are uncovered between the various centers, or unless we are talking about different diseases our present conclusion is that a malic enzyme deficiency is not the primary defect in most cases of Friedreich's disease. Whether its relative presence contributes to some of the symptoms is still a possibility, particularly if mitochondrial malic enzyme serves as a safety valve for Krebs cycle intermediates towards pyruvate and alanine. In such a situation, malic enzyme would be "down-regulated" in Friedreich's disease as a consequence or reflection of the energy defect, not as a cause. The fact that linoleic acid-treated patients have higher activities of the enzyme (VI-27), is a further argument for this interpretation. However, even without a defect in mitochondrial malic enzyme, there is strong evidence (reviewed in V-29) that many of the symptoms of Friedreich's disease are secondary to a deficiency in energy production, a finding on which all authors seem to agree.

\section{(c) Transport and Handling of Amino acids}

During the initial survey, we had demonstrated that the urinary excretion of taurine was increased in many, but not in all, patients with Friedreich's disease (I-19). Later it was shown that these patients do not handle a taurine load in a normal manner, excreting a higher proportion of the ingested load within a given time period, despite a normal pattern of their blood curve (III-24). In both these traits they resemble subjects with muscular dystrophy (VI-19). The extent of taurine handling appears to follow a genetic pattern (V-23), as described in other entities and normal control subjects by Goodman et al. (1980). The concentration of taurine in the cerebrospinal fluid is normal (II-13), but it is slightly elevated in the cerebellum (III-20) in Friedreich's disease. Studies on the uptake of taurine in platelets (II-12) and in fibroblasts (III-19; IV-19) are essentially normal in this disorder. Tissue concentrations in vivo, as measured in platelets, are normal in Friedreich's disease (VI-18), as is the serum concentration after a taurine load. Because of these considerations, a taurine transport defect causal to the disorder is now fairly well excluded. The explanation for the 
increased urinary taurine excretion at rest and after a taurine load still escapes us, but it is either related to a decrease in the muscle mass in these patients (and of the total taurine retention capacity), or to a taurine renal reuptake defect secondary to the primary biochemical deficit. For example, an increased taurine excretion is found in states of pantothenic acid deficiency, thus when co-enzyme A availability for energy related processes may be deficient (Koyanagi and Obori, 1965). Similarly, taurine excretion can be abnormal when the membrane content of linoleic acid is deficient (Yorek et al., 1984), as it is in Friedreich's disease (IV-17). As we will see later, both these possibilities should be explored further in that disorder.

Despite the fact that the taurine uptake mechanism is normal (II-12; III-19; IV-19) it should be remembered that when large amounts of taurine are needed for immediate protective purposes, such as when the heart hypertrophies (II-5; III-18), or for osmotic homeostatism (van Gelder, 1983; Thurston et al., 1981), this taurine can only come from the muscle pool. However, the muscle pool of taurine is progressively reduced in Friedreich's disease (VI-19). It is thus possible that these patients are in fact in a state of local relative taurine deficiency during periods of stress. Years ago, we had demonstrated a link between taurine and zinc (Barbeau and Donaldson, 1974). This aspect was investigated further in these patients, but zinc concentrations in hair were found to be essentially normal (VI-21) and not to be correlated to taurine levels in urine (VI-22). Zinc transport, however, may not be totally normal (VI-22).

Finally, it should be noted that the concentrations of other amino acids in blood, urine and tissues in vivo, were essentially normal in Friedreich's disease except for a few deviations whose significance is still unknown: increased urinary excretion of $\beta$-alanine (I-19); decreased blood concentration of glycine and aspartic acid (I-19) and increased serine/glycine ratio in platelets (V1-18).

As we stand in 1984, it is obvious that the basic defect in Friedreich's disease is not to be found in amino acid metabolism, but certain signs are probably a direct result of changes in the available concentration, at receptor sites (III-21), of specific amino acids: glutamic and aspartic acids for ataxia; taurine for cardiac hypertrophy, and possibly glycine for conjugation (see infra).

\section{(d) Lipid and Lipoprotein Metabolism}

Lipids and their transport lipoproteins are known to be involved in two entities closely related clinically to Friedreich's disease: Refsum's phytanic acid storage disease (Refsum, 1946) and a-betalipoproteinemia, or Bassen-Kornzweig disease (Bassen and Kornzweig, 1950). The finding of low normal cholesterol levels in most patients, coupled to significantly higher but still normal mean triglyceride levels (I-16) were also a stimulus for this work. Following upon these leads, the lipoprotein composition of the patients was studied. Major differences from control were reported in the high density lipoprotein (HDL) fraction (II-18). Their total amount was reduced and their composition was abnormal: the relative proportion of cholesterol and triglycerides was increased, while the relative protein content was greatly reduced. In further studies (III-23) it was shown that the protein fraction of HDL was normal in composition. Apoproteins $A_{1}$ and $A_{2}$ were within normal limits and so was the gel electrophoresis pattern. In more recent studies (VI-24), apoprotein E was also shown to be normal in quantity and in isoenzyme patterns. It was thus in the other fractions that it was necessary to search for the HDL anomaly. It was indeed shown that the fatty acid profile of the cholesteryl-ester (CE) fraction was deficient in 18:2 (linoleic acid) in both total plasma and HDL. This reduction in 18:2 was also present in the HDL phospholipid fraction.

The reduction in linoleic acid availability and transport has direct effects upon cell membrane structure and function. Because of substrate unavailability, Lecithin: cholesterol acyltransferase (LCAT) tends to be lower in these patients (IV-17) and red blood cell membranes have a lower content of phosphatidyl choline 18:2 (IV-17). These results have been confirmed (Amaducciet al., 1983). Similarly, lipoprotein lipase and hepatic lipase, because of substrate restriction, have lower activities in Friedreich's patients (V-20). Some of these findings were confirmed by Filla et al. (1980) in Italy and by Yao and Dyck (1978) in the U.S.A., but not by Walker et al. (1980) in England. There is no clear reason yet found to explain these differences. However it should be noted that such findings are not specific to Friedreich's disease (Yao and Dyck, 1979).

It is known that modifications in cell membrane fatty acid composition can change membrane "fluidity" and interfere with the function of a number of membrane-related enzymes (see review in IV-22). A remarkable correlation between the red blood cell membrane 18:2 content and each of the mitochondrial enzymes studied was observed in 7 patients with Friedreich's disease ( $V-29)$, thus confirming that the energy production defect is not the result of a primary Krebs cycle enzyme defect, but secondary to either a membrane deficit or the unavailability of substrate or co-factors during metabolic stresses. These conclusions are reinforced by the observation that correction of a linoleic acid deficiency also modifies the previously observed PDH deficit (V-25). The proportion of membrane linoleic acid, by affecting the structure of phospholipids (III-25) also influences the transfer of substances through membranes (Launay et al., 1981). Some evidence for membrane fluidity modifications have been presented in Friedreich's disease (1II-26, 27) but the changes are not major and appear to reflect secondary involvement of the protein structure of the membrane (III-26). However protein kinase activity in red blood cell membranes is normal (IV-16).

Obviously, membrane modifications in permeability, or "fluidity", would be reflected in changes at the level of membrane receptors. Only fragmentary evidence of this now exists. Thus some neurotransmitter receptors are not entirely normal in the cerebellum (III-21) and there is a strong possibility that insulin receptors are abnormal in the brain and elsewhere, as they are in diabetic Friedreich's patients in the monocytes (VI-23), to explain the observed insulin resistance. Although $\alpha$ and $B$-adrenergic receptors have not yet been studied, it should be noted that catecholamines (dopamine and norepinephrine) are evelated in those patients, as if there was an increased catecholamine resistance (V-21, 22). Such an increase in circulating catecholamines could be a contributing factor in the development of the hypertrophic cardiomyopathy (Cohen, 1974; Stanton et al., 1969) seen in these patients and of dysautonomia and labile hypertension (Margalith et al., 1984).

When membranes are damaged, this is sometimes reflected in other biochemical changes. In patients with Friedreich's ataxia, an abnormality in protoporphyrins was noted (III-15), but the most important change is in the increase in cholesteryl 
sulfate (VI-25) which was recently identified but is not yet fully explained.

The question remains as to the origin of the 18:2 deficiency in patients with Friedreich's disease. This deficiency is clearly illustrated by our so-called "FA index" (V-29) which apparently discriminates between patients with the disease, and normal controls. Enzymatic incorporation into intestinal phospholipids was actually found to be normal (V-29) and there is no reason to suspect a dietary imbalance, at least in adolescence and adult life. Studies to be detailed later may in fact increminate bile phospholipids as the source of this 18:2 deficit. It should, however, be stressed that such an 18:2 deficiency is not specific to Friedreich's disease.

In summary, we feel that a secondary defect in 18:2 availability or incorporation (in the liver most probably) can affect many of the enzymes essential to cell energy production, whose activities would be proportionally reduced and would favour the development of some of the major signs of the disease.

\section{(e) Liver Function}

The initial observation was made early and unexpectedly in this investigation (1-18): nearly $35 \%$ of our patients with typical Friedreich's disease had total and unconjugated bilirubin values above normal limits. This observation was confirmed in other series $(I V-3,4)$ but not in all patients. Combined metabolic stresses of fasting and injections of nicotinic acid did not modify the pattern (II-8): the high bilirubin ataxics maintained abnormally elevated levels of bilirubin under these conditions, while normal bilirubin ataxics behaved like the normal controls. The only conclusion justified from these studies is that, in some patients with Friedreich's disease, a conjugation defect is present in the liver. It is obvious, moreover, that a defect in bilirubin metabolism is not the primary defect in Friedreich.

This focus on the liver has recently been justified by other apparently unrelated studies. A qualitative metabolic profiling of $\alpha$-keto acids in Friedreich's disease (V-26) uncovered fortuitously that the urinary concentration of hippuric acid was considerably decreased in ataxic patients $(163.4 \mathrm{mg} / \mathrm{l})$ versus normal control subjects $(298.5 \mathrm{mg} / \mathrm{l})$. Hippuric acid is formed from the conjugation of benzoic acid with glycine in the liver. In 1936, Quick recommended the estimation of hippuric acid as a test of liver function. This test is probably the most practical to evaluate the ability of the liver to detoxify or conjugate, although it is rarely performed these days. As stated above, hippuric acid is formed from the conjugation of benzoic acid with glycine. This is a two step process: first benzoic acid reacts with coenzyme $\mathrm{A}(\mathrm{Co} A)$ in the presence of $\mathrm{Mg}^{++}$, and ATP to be "activated" into benzoyl S Co A by the action of Co A ligase, probably within the endoplasmic reticulum. This activated benzoyl CoA then conjugates with glycine, probably within Iysosomes, to give hippuric acid. This step is favoured by an $\mathrm{N}$-acyltransferase, possibly specific for phenolic acids.

In Friedreich's disease, hippuric acid formation from benzoic acid and glycine is markedly decreased, at metabolic rest (V-26) and during Quick's test (V-24) / $2.99 \mathrm{~g}$ hippuric acid (or benzoic acid) formed in 4 hours in normal controls - versus 1.55 $\mathrm{g}$ in ataxic patients; $\rho<0.001 /$. From our present available knowledge, a deficiency in the immediate availability of Coenzyme A under such a metabolic stress test, would be sufficient to explain all these findings. Such a defect may also be reflected in decreased acetylcholine formation in Friedreich's disease
(Gibson et al., 1975) and explain the partial improvement observed after physostigmine administration (Kark et al., 1977; II-19). Because the extent of the biochemical defect appears to vary with time, evolution of the disease, diet and other unknown factors, it is most likely that diminished activation by CoA is not the direct response of one or more defective enzymes in the liver, but rather the result of $\mathrm{CoA}$ availability restrictions in that organ. CoA is directly synthetized in the liver when needed rapidly, from pantothenic acid in the portal circulation. In rest conditions, most of the CoA utilized for normal metabolic activities is recycled CoA from acetyl $\mathrm{CoA}$ and other $\mathrm{CoA}$ complexes. If pantothenic acid were deficient, or not immediately available for rapid synthesis of CoA, deficient "activation" processes would result. Thus much recent evidence would favour in our patients a possible defect in $\operatorname{CoA}$ availability in the liver in periods of metabolic stress or rapid turnover. The resulting biochemical lesions would seriously impair, for example, the incorporation of many fatty acids into phospholipids, the formation of phosphatidyl choline (Mahboob, 1975), and most bile conjugation and transport mechanisms (see supra).

\section{Friedreich's Disease 1984: Accomplishments and Prospects For} the Future

Where do we stand in 1984 after nearly 10 years of very intensive investigation? Did we progress in a way that justified the expanditure in time, money and personnel? There is no doubt that we have made important and crucial advances in the clinical definition and nosology of the various hereditary ataxias and have unravelled many of the diagnostic criteria which permit further biochemical investigations to be carried out systematically. The horizon of hereditary ataxias and particularly of Friedreich's disease is much clearer in 1984 than it was in 1974. Many of the causes of confusion have been eliminated or clarified. The picture,unfortunately, is not as obvious with regards to the progress in biochemistry.

When this Cooperative Study was conceived, it was hoped that a systematic survey of the known biochemical and metabolic pathways would clearly point the way to the primary defect in Friedreich's disease and that this approach would be far superior to the "classical" serendipity approach. The initial survey during Phase One did uncover at least five promising leads which were subsequently explored systematically: possible defects in glucose and insulin metabolism, in pyruvate metabolism, in the transport and handling of certain amino acids, in lipid and lipoproteins and finally in hepatic cell function (see above). Unfortunately the final answer was not to be found directly at the foot of the rainbow. All these leads eventually contributed to the understanding of the pathophysiology of many signs and symptoms (ex.: low aspartate and glutamate concentrations and ataxia; low energy production and the dyingback phenomenon), but no major and constant enzymatic defect was uncovered in any of these metabolic pathways that could be conclusively called the cause of Friedreich's disease, like the defect in $\alpha$-hydroxylation of phytanic acid in Refsum's disease, although very few steps were left unexplored. Some apparent defects received momentary limelight, but could not withstand the test of time.

Where did we go wrong. . . or did we? Friedreich's disease is an autosomal recessive disorder, so it was normal to consider that an enzyme block would be found in a given biochemical 
pathway. When this occurs, abnormally high precursors or abnormally low metabolites are usually found along the involved pathway. None of our studies were successful in identifying such changes. The focus of our attention was drawn to so-called "metabolic" pathways, because the frequent presence of diabetes led us to think that way. Again all our detailed investigations of these pathways were unrewarding.

Because theoretical considerations made it obvious that the energy production mechanism could be severely impaired, at least in large myelinated fibers and cell bodies, most of our efforts (and they were numerous) were concentrated upon the enzymes of the Krebs cycle or of phosphorylation. Many defects were reported (PDH, LAD, VDH, GDH and more recently malic enzyme), but controlled studies eventually showed all these deficiencies to be secondary, partial or inconstant, probably because they reflected an underlying changing environment (II-20; 111-28).

Was this approach wrong and wasteful, while the defect lies hidden in a still unexplored metabolic pathway? We think not. It appears to us that the systematic investigation was done thoroughly and covered a sufficient number of bases to avoid missing important steps along the way, and it is more than probable that the pathways least explored, like purine metabolism (II-17), prostaglandins (II-6) and others would not reveal major blocks after more thorough investigation.

We must then look at our facts in a different, and new way: could it be that all the small and relative changes in glucose, pyruvate, amino acids, lipids and their enzymes are real, but secondary to a defect outside these metabolic pathways, a common regulatory type of deficiency which has the main characteristic of being variable over time according to the circumstances (or to diet?). Such a possibility, for example, could be a deficiency in co-factors, vitamins or trace metals (zinc, see VI-22).

Recent interest has focussed on the neurological syndromes accompanying deficiencies in three vitamins: Vit. E, Biotin and Pantothenic acid. The study of how these deficiencies cause their specific neurological damage deserves further attention if we are to unravel the mysteries of Friedreich's ataxia, as possible models or as important clues to the eventual etiology of the disease.

\section{(a) Vitamin $E$}

Initial studies on the pathophysiology of Bassen-Kornzweig disease at first tried to blame entirely the absence of betalipoproteins and the subsequent defects in other lipids and lipoproteins. Now it appears that the entire neurological disorder is due to lack of Vitamin $E$ resulting from impaired intestinal absorption of lipids and lipidsoluble vitamins (Muller et al., 1983; Bieri et al., 1983; Rowland, 1983). Rowland best reviewed the accumulated evidence for this conclusion:

1. "The neurologic disorder of abetalipoproteinemia includes cerebellar ataxia, loss of posterior column sensory functions, sensori-motor peripheral neuropathy, and myopathy (Nelson et al., 1981 - review in Muller et al., 1983). All of these manifestations have been seen in other forms of human Vitamin $\mathrm{E}$ deficiency (often non genetic) due to malabsorption in celiac disease, impaired secretion of bile salts, exclusive bowel resection, or cystic fibrosis" (Elias et al., 1981: Werlin et al., 1983). The syndrome can even occur in the absence of overt malabsorption (VI-9).
2. "Untreated, almost all children with abetalipoproteinemia had neurologic abnormality by age 10 , the minimal sign was loss of knee and ankle jerks. Muller et al. (1983), Elias and Muller (1983) have treated abetalipoproteinemic children with Vitamin E. If treatment started before there were signs of neurologic disorder, none appeared. In other patients there was no progression of prior disability, and in a few there was improvement of ataxia, nerve conduction velocities, or tests of retinal function'. (Bieri et al., 1984; Bishara et al., 1982).

Thus these secondary spinocerebellar disorders are phenocopies of genetic entities such as Bassen-Kornzweig disease and possibly Friedreich's disease. In all these entities a Vitamin E deficiency seems to be the cause of the neurological impairment. Nelson et al. (1981) have suggested that chronic and severe Vitamin E deficiency in rats, monkeys, and human beings leads to degeneration and loss of sensory axons in the posterior columns, sensory roots, and peripheral nerves with a selective loss of large calibre myelinated sensory axons. They also postulated that this degeneration results from axonal membrane injury and then develops as a distal and dying-back type of axonopathy. The mode of action of Vitamin $\mathrm{E}$ in the nervous system is not yet established. It appears to be important in maintaining the integrity and stability of biological membranes (Muller et al., 1983).

Vitamin $E$ status has been determined in typical cases of Friedreich's disease because an early finding was the low concentration of betalipoproteins in some of these patients (II-4: controls $713 \pm 248$; Friedreich $569 \pm 277 \mathrm{mg} \%$ ). The results (III-24) were at the lower limits of the normal range (controls $0.69 \pm 0.04$; Friedreich $0.61 \pm 0.04 \mathrm{mg} \%$ ) in adult cases of the disease. Thus, although a deficiency in Vitamin $E$ may have existed in the very early years of development and growth (still to be demonstrated), there is no evidence of a severe Vitamin $\mathrm{E}$ deficiency in advanced cases of Friedreich's disease. Still to be investigated is the possibility that despite almost normal concentrations, Vitamin Edoes not exert its effects in Friedreich's disease because of membrane changes or interference with its post-receptor biochemical mechanism, or "dependancy".

\section{(b) Biotin}

Biotin is possibly one of the least known of the vitamins. Bound biotin plays a role as an intermediate carrier of carbon dioxide during the action of certain carboxylating enzymes. Tricarboxylic acid cycle intermediates can be replenished by special enzymatic reactions called anaplerotic ("filling-up") reactions. The most important in the liver and kidneys is the enzymatic carboxylation of pyruvate to form oxaloacetate. Malic enzyme is also involved in an anaplerotic reaction. Pyruvate carboxylase is a mitochondrial enzyme and contains four molecules of biotin covalently attached to the four subunits of the enzyme. This enzyme is allosteric. Its forward reaction, leading to oxoloacetate formation, is negligible unless Aceryl-Co $A$, its positive modulator, is present. This point may be very important to remember in understanding Friedreich's disease.

Biotin-responsive multiple carboxylase deficiencies are heritable metabolic disorders that present in the neo-natal period as a form of congenital lactic acidosis (Parkman et al., 1981 a) and later in infancy with skin rash, alopecia and intermittent ataxia (Packman et al., 1981 b; Sander et al., 1980; Thoene and Wolf, 1983). Sander et al. (1982), in a rat model of biotin deficiency, demonstrated that hepatic pyruvate carboxylase activity was 
$3 \%$ of control, whereas pyruvate carboxylase activities of all brain sections, including the cerebellum, were 53 to $71 \%$ of control. Cerebellar pyruvate carboxylase activity is therefore not distinctly low or labile and is in fact preferentially maintained despite severe cofactor deprivation. This may explain why the cerebellar symptomatology is slow in developing.

In preliminary studies pyruvate carboxylase activity was shown to be markedly reduced in Friedreich's disease (Dijkstra et al., 1983), particularly in liver biopsies.

\section{(c) Pantothenic Acid}

The third vitamin which may be responsible for neurological signs like those found in Friedreich's disease is pantothenic acid. Pantothenic acid is one of the $B$ vitamins and thus cannot be synthesized by animals. Microorganisms, on the other hand, make this vitamin from its precursors, pantoic acid and betaalanine. Pantothenic acid forms one of the most important coenzymes, coenzyme $A$, in which the $S H$ group represents the active site of the molecule; its highly energetic bond with acyl radicals forms thioesters called acyl-CoA. Such Acyl-CoA are the "active" form of these radicals and can be used as such by the organism. The main function of coenzyme $A$ is thus to confer to fatty acids a high energy potential which allows them to react. Pantotheine is the functional group of $\mathrm{CoA}$ acyl carrier protein and guanosine 5'-triphosphate (GTP)-dependent acyl CoA synthetase. CoA is enzymatically involved in acetylation of amines (including choline sulfonamides, $\rho$-amino-benzoate), oxidation of pyruvate and $\alpha$-ketoglutarate, and fatty acid B-oxidation. It is also involved in the synthesis of fatty acids, cholesterol, sphingosine, citrate, acetoacetate and porphyrins.

The normal intake of pantothenic acid by human beings taking mixed diets is between 7 and $10 \mathrm{mg}$ per day. Serum contains free pantothenic acid, but CoA is the form found in tissue including red blood cells. Free pantothenic acid is contained in plasma in amounts of 6 to $8 \mu \mathrm{g}$ per deciliter. Pantothenic acid is present in whole blood in amounts ranging between 100 and $180 \mu \mathrm{g}$ per deciliter. Values less than $80 \mu \mathrm{g}$ per deciliter would be considered to be suggestive of pantothenic acid deficiency.

Pantothenic acid deficiency occurs rarely in humans because the vitamin is frequent in most foods in the North American and British diets (Walsh et al., 1981; Tarr et al., 1981; Bull and Buss, 1982). However, an old literature exists which makes the possibility of pantothenic acid deficiency pertinent to Friedreich's disease: in pigs, pantothenic acid deficiency produces ataxia, spasms, pareses, postural anomalies, walking disturbances. Pathologically the sensory neurons and the dorsal column and dorsal root ganglia bear the brunt of the changes (Wintrobe et al., 1942, 1943; Swank and Adams, 1948). Some of these changes are responsive to therapy with pantothenic acid, others only to pyridoxine. In more recent studies Hurley and Volkert (1965) found that pantothenate and $\mathrm{CoA}$ levels in livers of fetal guinea pigs increased abruptly at $\mathbf{5 8}$ days of gestation after remaining constant from 33 to 48 days. These results suggested that the period just before birth might be very critical with respect to pantothenic acid. A deficiency at that time may be sufficient to favour lesions in the dorsal columns and ganglia, very early in the life of the Friedreich's patients. This aspect should be studied in more detail.

As noted before mammalian tissues synthesize CoA from pantothenate, cysteine and ATP with pantotheine as an interme- diate step. In the liver, hormonal regulation of the pantothenate CoA metabolic pathway occurs independent of the influx of metabolic fuels (Smith et al., 1978). Pantothenic acid is indeed taken up by tissues under metabolic or hormonal control. Decreased uptake by muscle and increased uptake by liver may represent a mechanism for shifting large body stores of pantothenic acid present in muscles to the liver, in which endogenous pantothenic acid concentrations are normally low (Reibel et al., 1981). Again, it should be noted that CoA from the blood does not permeate well into liver cells (Domschke et al., 1971), therefore new CoA needed in conditions of metabolic stress such as exposure to cold (Tsujikawa and Kimura, 1981) must be synthesized locally in the liver from free pantothenic acid. The availability, uptake or supply of pantothenic acid, as well as its incorporation into $\mathrm{CoA}$, then become the crucial limiting factors for rapid liver synthesis of new CoA for a host of metabolic reactions (previously listed). This availability can be reduced at given moments during life, either by dietary deprivation or through the effects of diabetes and other metabolic diseases upon its uptake system. Thus a mechanism exists for a relative deficiency of pantothenic acid early in life and as a progressive phenomenon later, for example, in the presence of diabetes. Nevertheless, it should be remembered that even in the face of low pantothenic acid concentration, tissue CoA levels (heart and liver) tend to remain at control levels, or even increase in fasting and diabetes (Reibel et al., 1982), probably to compensate for the inability to form new $\mathrm{CoA}$ in an emergency. Despite this normal or elevated liver level of CoA in pantothenic acid deficiency, neurological and growth damage still occur, confirming the hypothesis that we are in the presence of a functional deficiency of new CoA formation in these conditions.

Few data exist on the actual tissue and blood levels of pantothenic acid and CoA in ataxic syndromes, and particularly in Friedreich's ataxia, despite the numerous arguments in favour of the involvement of this vitamin in this disorder. These studies are being carried out. If a functional deficiency could be demonstrated, a certain number of biochemical observations made during our Cooperative Study could be partially explained: thus in pantothenic acid deficiency there is an increased urinary excretion of taurine (Koyanagi and Obori, 1965; Marks and Berry, 1962) and of porphyrins (Mahboob and Estes, 1978), while this deficiency is accompanied by a significant decrease in phosphatidyl choline formation (Mahboob, 1975) and an impairment of the elongation and desaturation process of polyunsaturated fatty acids, particularly linoleic acid (Fidanza and Audisio, 1982).

Although we have not detailed the arguments for such a possibility, one must remember that the co-factor defect we are searching for could be at the level of trace metals. The most likely element for investigation should be zinc (Barbeau and Donaldson, 1974; VI-22).

\section{Conclusions}

The autosomal recessive form of ataxia known as Friedreich's disease has resisted the systematic investigation of most metabolic pathways during the nearly ten years of the Quebec Cooperative Study, without yielding its final secret. No abnormal increase in precursor substances, or unwanted decreases in the concentration of metabolites, were found which could have given us the kind of lead which helped solve Refsum's disease. 
Nor did we find, histologically, evidence for a form of storage disease like in the lysosomal disorders. In brief, no clear-cut, marked, constant and undeniable block in the activity of a given enzyme was found.

Instead, the biochemistry of Friedreich's disease is characterized by a multitude of partial enzymatic deficiencies in some but not all patients. Most of these deficiencies concern the energy production mechanisms, but this is not exclusive. In an attempt to explain the above-noted failure in localizing the enzyme block and the partial deficits, we have been forced to turn to new hypotheses. Thus we first postulated that some of these defects are secondary to a breakdown in membrane fluidity and integrity (which the body tries to correct by increasing cholesteryl sulfate, a membrane stabilizer, for example; see VI-25) at the level of important cells in the dorsal root ganglia and myelinated fibers from that ganglion.

The other postulate we would like to make is that most of the previously noted partial defects are the results of a decreased functional availability of some cofactors at certain moments of increased need, such as metabolic stresses (fasting, diabetes) or growth (birth, puberty, pregnancy). Selected for special attention were Vitamin E, Biotin, Pantothenic acid which can all produce, singly or in combination, damage to the nervous system, particularly the sensory nervous system. By "decreased availability", at this stage, we encompass defects in the supply in the diet, malabsorption, abnormal transport or incorporation and specific receptor reactivity. Thus deficiency or dependancy states both have to be considered, studied and evaluated. At this time, the author feels that this is the best line of research to pursue in view of the present knowledge, patiently accumulated as a mosaic of data over the last 10 years.

In parallel, because of the unique opportunity offered researchers by the concentration of so many cases descending from a single ancestor (see VI-2), the author feels that a major effort should be directed towards the localization of the Friedreich's gene with the use of the new molecular genetic techniques now available. This opinion is also based on the recent results in Huntington's chorea by Gusella and collaborators (1983).

It is hoped that the next 10 years, failing success in the first 10 years of our research, will finally reward Claude Saint-Jean for his foresight and tenacity in creating the "Association Canadienne de l'Ataxie de Friedreich", which has funded all of the research of the Quebec Cooperative Study. In this respect, it may be of interest to readers to know that since 1974 the Association has spent \$2,338,000.00 dollars (Can.) upon 207 peer-approved awards,contracts and grants (average $\$ 11,295.00$ per grant). These projects (see Table 2 ) have truly been of an international nature, involving, over 10 years, 242 scientists from 43 institutions in 8 countries. These numerous collaborators have, to date and including the present issue, contributed 148 scientific papers to the literature. 151 of the collaborators have made only occasional, if significant, contributions; 67 contributed in 2 to 4 projects, while 24 scientists were involved in a large number of projects throughout the 10 year period (range 5 to 93 individualized contributions; mean 14.75 per contributor). This gigantic effort is a realization for which we must be proud, and the motivation for continued enthusiasm.

\section{DISTRIBUTION OF COLLABORATORS (CO-AUTHORS)}

\begin{tabular}{lcc} 
A - Country of Origin & $\begin{array}{c}\text { No. Institutions } \\
\text { Participating }\end{array}$ & $\begin{array}{c}\text { No. Collaborators } \\
\text { Participating }\end{array}$ \\
1. CANADA (Quebec) & 18 & 141 \\
2. CANADA (Other & & \\
$\quad$ Provinces) & 6 & 19 \\
3. U.S.A. & 5 & 15 \\
4. FRANCE & 4 & 18 \\
5. SPAIN & 4 & 5 \\
6. ITALY & 2 & 24 \\
7. GREAT BRITAIN & 2 & 2 \\
8. URUGUAY & 1 & 16 \\
9. ALGERIA & 1 & 242 \\
\multicolumn{1}{c}{ TOTAL } & $\underline{43}$ & $\underline{242}$
\end{tabular}

\section{B - PUBliCATIONS}

1. TOTAL NUMBER OF PUBLISHED PAPERS: 148

2. CONTRIBUTION OF COLLABORATORS:
A - One contribution only:
B - 2-4 contributions
C -5 or more contributions
67 collaborators
24 collaborators

\section{ACKNOWLEDGEMENTS}

The studies from the author's laboratories, as well as all other projects in this Quebec Cooperative Study, were supported by grants from "L'Association Canadienne de l'Ataxie de Friedreich". Special thanks are due also to "le Ministère des Affaires Sociales du Québec" who permitted and funded the hospital based studies and to the Ministry of National Health and Welfare (and particularly to its Minister, the Honorable Monique Bégin) for numerous special grants to help in the administration of the Association and its fund-raising efforts; to the patients who smilingly participated in all these studies and to their myriad friends who contributed the funds for the research; finally to all our collaborators during these last 10 years. We owe a special debt to Mrs. Nicole Guay-Poirier who acted as Executive Secretary for this special issue. 


\section{REFERENCES}

\section{Reference Code for Quebec Cooperative Study}

Note: Instead of enumerating complete references for the 148 papers comprising the Quebec Cooperative Study of Friedreich's Ataxia, these will be listed in the text under the issue number (I to VI) and with the consecutive article number. Thus the reference "BARBEAU, A. "Friedreich's Disease 1982: Etiologic Hypotheses - A Personal Analysis", CJNS, Vol. 9: 243-263", would be cited in the text as V-29

No.

\section{FIRST AUTHOR}

\section{CONDENSED TITLE}

FIRST PAGE

\section{I- 1976 Issue of CJNS Vol 3 pp. 269-to-397}

$\begin{array}{rll}\text { I }-1 & \text { BARBEAU } \\ 2 & \text { ANDERMANN } \\ 3 & \text { GEOFFROY } \\ 4 & \text { ANDERMANN } \\ 5 & \text { BARBEAU } \\ 6 & \text { CADOTTE } \\ 7 & \text { REMILLARD } \\ 8 & \text { PEYRONNARD } \\ 9 & \text { COTE } \\ 10 & \text { MALO } \\ 11 & \text { GATTIKER } \\ 12 & \text { COTE } \\ 13 & \text { GUERIN } \\ 14 & \text { BUREAU } \\ 15 & \text { SANCHEZ-CASIS } \\ 16 & \text { BUTTERWORTH } \\ 17 & \text { SHAPCOTT } \\ 18 & \text { BARBEAU } \\ 19 & \text { LEMIEUX } \\ 20 & \text { BARBEAU } \\ 21 & \text { BARBEAU }\end{array}$

$\begin{array}{ll}\text { Design of Investigation } & 271 \\ \text { History } & 275 \\ \text { Clinical Criteria } & 279 \\ \text { Genetics } & 287 \\ \text { Genealogy in Quebec } & 303 \\ \text { Chromosomes } & 307 \\ \text { E.E.G. } & 309 \\ \text { Nerve Conduction } & 313 \\ \text { Cardiac Signs and Symptoms } & 319 \\ \text { E.C.G. and Vectocardiogram } & 323 \\ \text { Echocardiogram } & 329 \\ \text { Hemodynamics } & 333 \\ \text { Angiography } & 337 \\ \text { Pulmonary Functions } & 343 \\ \text { Pathology of the Heart } & 349 \\ \text { Clinical Laboratory Findings } & 355 \\ \text { Glucose and Insulin Metabolism } & 361 \\ \text { Bilirubin Metabolism } & 365 \\ \text { Amino acids } & 373 \\ \text { Pyruvate Metabolism } & 379 \\ \text { Overview } & 389\end{array}$

II- 1978 Issue of CJNS Vol. 5 pp. 55-10-165

$\begin{array}{rrl}\text { II }-\quad 1 & \text { BARBEAU } \\ 2 & \text { BOUCHARD } \\ 3 & \text { MONDAY } \\ 4 & \text { WASTIAUX } \\ 5 & \text { HUSTABLE } \\ 6 & \text { HORROBIN } \\ 7 & \text { BUREAU } \\ 8 & \text { HAMEL } \\ 9 & \text { NGO } \\ 10 & \text { FILLA } \\ 11 & \text { MELANCON } \\ 12 & \text { FILLA } \\ 13 & \text { LEMIEUX } \\ 14 & \text { BUTTERWORTH } \\ 15 & \text { BUTTERWORTH } \\ 16 & \text { COLLU } \\ 17 & \text { DRAPER } \\ 18 & \text { HUANG } \\ 19 & \text { BARBEAU } \\ 20 & \text { BARBEAU }\end{array}$

Statement of Problems

Charlevoix-Saguenay Syndrome (ARSAC)

ENG 71

OPCA $\quad 75$

Cardiac Pharmacology $\quad 83$

Prostaglandins $\quad 93$

Oxygen Transport $\quad 97$

$\begin{array}{ll}\text { Familial Hyperbilinubinemia } & 101\end{array}$

LAD Regulation $\quad 105$

Serum and Platelet LAD 111

Fibroblast LAD $\quad 115$

Platelet Taurine Uptake $\quad 119$

$\begin{array}{ll}\text { Taurine in CSF } & 125\end{array}$

3-Acetylpyridine Ataxia $\quad 131$

Alloxan Diabetes 135

Taurine and Morphine $\quad 139$

Purine Metabolism 143

Plasma Lipids and Lipoproteins $\quad 149$

$\begin{array}{ll}\text { Emerging Treatments } & 157\end{array}$

Overview 161

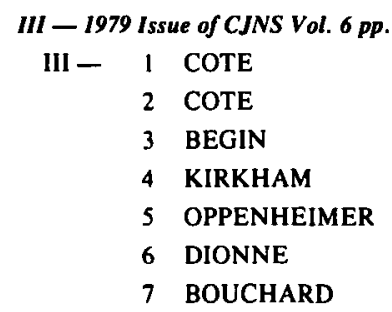

Cardiac Function in Heterozygotes $\quad 147$

Evolution of Cardiac Function 151

Regulation of Respiration

$\begin{array}{ll}\text { Oculomotor Anomalies } & 167\end{array}$

Brain Lesions 173

Vestibular Findings in ARSACS $\quad 177$

Electrophysiology in ARSACS $\quad 185$ 
8 BOUCHARD

9 LANGELIER

10 PEYRONNARD

11 BOUCHARD

12 JOLICOEUR

13 BUTTERWORTH

14 AZARI

15 MORGAN

16 DRAPER

17 MELANCON

18 HUE

19 MELANCON

20 HUXTABLE

21 REISINE

22 MELANCON

23 DAVIGNON

24 FILLA

25 DRAPER

26 BUTTERFIELD

27 STEINBERG

28 BARBEAU

IV- 1980 Issue of CJNS Vol. 7 pp. 337-10-468

$\begin{array}{rll}\text { IV }- & 1 & \text { POURCHER } \\ 2 & \text { BOUCHARD } \\ 3 & \text { CAMPANELLA } \\ 4 & \text { D'ANGELO } \\ 5 & \text { RICHARDS } \\ 6 & \text { PASTERNAC } \\ 7 & \text { ALLARD } \\ 8 & \text { LAMARCHE } \\ 9 & \text { TOLIS } \\ 10 & \text { TOLIS } \\ 11 & \text { DRAPER } \\ 12 & \text { BERTAGNOLIO } \\ 13 & \text { MELANCON } \\ 14 & \text { FILLA } \\ 15 & \text { BARBEAU } \\ 16 & \text { WONG } \\ 17 & \text { HUANG } \\ 18 & \text { AZARI } \\ 19 & \text { MELANCON } \\ 20 & \text { BUTTERWORTH } \\ 21 & \text { DE MICHELE } \\ 22 & \text { BARBEAU } \\ & \end{array}$

$V-1982$ Issue of CJNS Vol. 9 pp. 95-to-263

$V$ - I BARBEAU

2 SALISACHS

3 ALLARD

4 ALLARD

5 ALLARD

6 VEZINA

7 TAYLOR

8 LAMARCHE

9 BARBEAU

10 FILLA

11 MELANCON

12 MELANCON

13 MELANCON

14 DE SMET
EEG and ARSACS

CT Findings in ARSACS

191

Nerve Conduction in ARSACS 199

Cluster of FA 205

Ataxia in the Rat 209

Thiamine Deficiency $\quad 217$

Syrian Golden Hamster $\quad 223$

Protoporphyrins $\quad 227$

Glucose Tolerance $\quad 233$

PDH/LAD in Fibroblasts 241

Electrophysiology of Taurine $\quad 243$

Taurine Uptake in Fibroblasts $\quad 251$

Brain Amino acids $\quad 255$

Receptors in Brain $\quad 259$

Glutamate Uptake in Fibroblasts $\quad 263$

Linoleic Acid and Lipoproteins $\quad 275$

Membranes and Transport $\quad 285$

Erythrocytes Membranes $\quad 291$

Membrane Proteins 295

Lectins $\quad 299$

Overview 311

Scoring and Stagging $\quad 339$

Ataxia and Amyotrophy $\quad 345$

Ataxia in Southern Italy 351

Ataxia in Northern Italy $\quad 359$

Dynamic Muscle Function $\quad 367$

Hypertrophic Cardiomyopathy $\quad 379$

Scoliosis $\quad 383$

Cardiomyopathy (Pathology) $\quad 389$

Serum Glucose in Heterozygotes $\quad 397$

Growth Hormone in Heterozygotes $\quad 401$

Glycosylated Hemoglobins $\quad 405$

PDH/LAD in fibroblasts $\quad 409$

LAD and Lecithin $\quad 413$

Pyruvate dehydrogenase in Platelets $\quad 417$

GDH $\quad 421$

Protein Kinase Activity $\quad 425$

LCAT Activity $\quad 429$

Taurine and Cardiomyopathy $\quad 435$

B-amino acid Transport $\quad 441$

Cerebral Amino acid manipulation $\quad 447$

Glutamate and Ataxia $\quad 451$

Overview - Pathophysiology $\quad 455$

Classification of Recessive Ataxias $\quad 95$

CMT and FA $\quad 99$

Scoliosis $\quad 105$

Pes Cavus Radiography $\quad 113$

Kinematics of the Foot $\quad 119$

Urodynamic Evaluation $\quad 127$

Auditory System 131

Spinal Ganglion Biopsy 137

Threonine and Spasticity $\quad 141$

Phosphatidylcholine $\quad 147$

Lecithin and Linoleic Acid 151

Lecithin and Linoleic Acid 155

Lecithin and Linoleic Acid $\quad 165$

Gamma-Vinyl GABA 171 


$\begin{array}{ll}15 & \text { JOLICOEUR } \\ 16 & \text { DE MICHELE } \\ 17 & \text { HUANG } \\ 18 & \text { MESSER } \\ 19 & \text { TOLIS } \\ 20 & \text { BLACHE } \\ 21 & \text { PASTERNAC } \\ 22 & \text { MERKEL } \\ 23 & \text { BARBEAU } \\ 24 & \text { BARBEAU } \\ 25 & \text { LORIETTE } \\ 26 & \text { BERTRAND } \\ 27 & \text { BARBEAU } \\ 28 & \text { BARBEAU } \\ 29 & \text { BARBEAU }\end{array}$

\section{VI - 1984 Issue of CJNS Vol. 11 pp. 501-to-660}

$\begin{array}{rll}\mathrm{VI}- & 1 & \text { BARBEAU } \\ 2 & \text { BARBEAU } \\ 3 & \text { BARBEAU } \\ 4 & \text { BARBEAU } \\ 5 & \text { BARBIERI } \\ 6 & \text { CHOUZA } \\ 7 & \text { BOUCHARD } \\ 8 & \text { RICHARDS } \\ 9 & \text { LAPLANTE } \\ 10 & \text { BOGACZ } \\ 11 & \text { MONDAY } \\ 12 & \text { BILLIMORIA } \\ 13 & \text { SIROIS } \\ 14 & \text { ALLARD } \\ 15 & \text { THERIAULT } \\ 16 & \text { LAMARCHE } \\ 17 & \text { BARBEAU } \\ 18 & \text { RODRIGUE } \\ 19 & \text { LEMIEUX } \\ 20 & \text { HUXTABLE } \\ 21 & \text { BARBEAU } \\ 22 & \text { SHAPCOTT } \\ 23 & \text { FANTUS } \\ 24 & \text { BOUTHILLIER } \\ 25 & \text { NESTRUCK } \\ 26 & \text { MELANCON } \\ 27 & \text { BARBEAU } \\ 28 & \text { BARBEAU }\end{array}$

$\begin{array}{ll}\text { 3-AP and Nicotinamide } & 175 \\ \text { Glutamate and Acrylamide Ataxia } & 179 \\ \text { Lipids in Acrylamide Ataxia } & 181 \\ \text { Dystonia Musculorum Mice } & 185 \\ \text { TRH Response in Ataxia } & 189 \\ \text { Lipoprotein Lipase } & 191 \\ \text { Catecholamines } & 195 \\ \text { Catecholamines } & 205 \\ \text { Urinary Taurine Excretion Pattern } & 209 \\ \text { Hippuric Acid Formation } & 217 \\ \text { PDH and Linoleic Acid } & 221 \\ \alpha-\text { Keto Acids } & 231 \\ \text { Valine dehydrogenase } & 235 \\ \text { Valine Load Test } & 239 \\ \text { Overview - Etiologic Hypotheses } & 243\end{array}$

Classification of Ataxias $\quad 501$

Origin of FA in Quebec $\quad 506$

Machado-Joseph Disease $\quad 510$

Acadian Ataxia $\quad \mathbf{5 2 6}$

Roussy-Levy Syndrome $\quad 534$

Spastic Ataxia + Ehler Danlos $\quad \$ 41$

Familial Periodic Ataxia $\quad 550$

Acetazolamine in FA $\quad 554$

Vit E Deficiency

Evolution of Visual Evoked Potentials $\quad 565$

ENG Evolution $\quad 570$

Foot X-Rays $\quad 574$

Foot Deformities $\quad 578$

Scoliosis Assessment $\quad 582$

Cardiomyopathy and Thallium $\quad 588$

Neuropathology of FA in Quebec $\quad 592$

Lysosomal Enzymes 601

$\begin{array}{ll}\text { Platelet Taurine } & 607\end{array}$

Urinary Taurine $\quad 610$

Amino acids in the Heart $\quad 616$

Hair Zinc $\quad 620$

Zinc and Taurine $\quad 623$

Insulin Resistance (paper withdrawn)

Cholesteryl-sulfate $\quad 631$

Malic Enzyme in Fibroblasts $\quad 637$

Malic Enzyme in Heart $\quad 643$

Overview - 10 Years of Research $\quad 646$

\section{REFERENCES}

Anaducci L, Paci C, de Scisciolo G, Mariana P(1983) Abnormal plasma lecithin cholesterol acyltransferase in hereditary ataxias. Neurology 33 (suppl. 2): 244.

Barbeau A (1975) Preliminary studies on pyruvate metabolism in Friedreich's ataxia. Trans Am Neurol Assoc 100: 164-165.

Barbeau A (1980) Distribution of ataxia in Quebec. In: (Japan Med. Res. Found., ed.), Spinocerebellar Degeneration, Tokyo, Univ. Tokyo Press, pp. 121-142.

Barbeau A, Donaldson J (1974) Zinc, taurine and epilepsy. Arch. Neurol. 30: 52-58.

Barbeau A, Giroux JM (1972) Erythrokeratodermia with ataxia. Trans. Amer Neurol Ass 97: 55-56.

Bassen FA ,Kornzweig AL (1950) Malformation of the erythrocytes in a case of atypical retinitis pigmentosa. Blood 5: 381-386.
Bieri JG, Corash L, Hubbard VS (1983) Medical uses of Vitamin E (Medical Progress). New Engl J Med 308: 1063-1071.

Bieri JG, Hoeg JM, Schaffer EJ, Zech LA. Brewer B (1984) Vitamin A and Vitamin $\mathrm{E}$ replacements in abetalipoproteinemia. Ann Int Med 100: 238-239.

Bishara S, Merin S, Cooper M, Azizi E, Delpre G, Deckelbaum RJ (1982) Combined Vitamin $A$ and $E$ therapy prevents retinal electrophysiological deterioration in abetalipoproteinaemia. Brit $\mathrm{J}$ Ophthalm. 66: 767-770.

Blass JP, Kark RAP, Menon NK (1976) Low activities of the pyruvate and oxoglutarate dehydrogenase complexes in five patients with Friedreich's ataxia. New Engl J Med 295: 62-67.

Bottachi E, Di Donato S (1983) Skeletal muscle NAD (P) and NADP ${ }^{+}$-dependent malic enzyme in Friedreich's ataxia. Neurology (Clev.) 33: $712-716$ 
Boyer SH, Chisholm AW, McKusick VA (1962) Cardiac aspects of Friedreich's ataxia. Circulation 25: 493-505.

Butl NL, Buss DH (1982) Biotin, pantothenic acid and Vitamin $\mathrm{E}$ in the British household food supply. Human Nutrition: Applied Nutrition 36 A: 190-196.

Butterworth RF, Giguère JF (1982) Glutamic acid in spinal cord gray matter in Friedreich's ataxia. New Engl J Med 307: 897.

Cacace AT, Satya-Murti S, Grimes CT (1983) Frequency, selectivity and temporal processing in Friedreich's ataxia - Clinical aspects in two patients. Ann Otol, Rhinol and Laryngol 92: 276280.

Cohen J (1974) Role of endocrine factors in the pathogenesis of cardiac hypertrophy. Circ Res 35 (suppl. II): 49-57.

Dijkstra UJ, Willem JL, Joosten EMG, Gabreels FJM (1983) Friedreich's ataxia and low pyruvate carboxylase activity in liver and fibroblasts. Ann Neurol 13: 325-327.

Domschke W, Liersch M, Decker K (1971) Lack of permeation of Coenzyme A from blood into liver cells. Hoppe-Seyler's Z Physiol Chem 352-85-88.

Dunn HG (1973) Nerve conduction studies in children with Friedreich's ataxia and ataxia-telangiectasia. Develop Med Child Neurol 15: 324-337.

Duvoisin RC, Chokroverty S, Lepore F, Nicklas W (1982) Glutamate dehydrogenase deficiency in patients with olivopontocerebellar atrophy. Neurology (Clev.) 33: 1322-1326.

Dyck PJ, Lambert EH (1968) Lower motor and primary sensory neuron diseases with peroneal muscular atrophy. II Neurologic, genetic and electrophysiologic findings in various neuronal degenerations. Arch Neurol (Chic) 18: 619-625.

Elias E.. Multer DPR (1983) Use of Vitamin E for prevention and treatment of spinocerebellar disorders. Comprehensive Ther. 9: 56-60.

Elias E, Muller DPR, Scott J (1981) Association of spinocerebellar disorders with cystic fibrosis or chronic childhood cholestasis and very low serum Vitamin E. The Lancet 2: 1319-1321.

Evans OB (1980). Muscle pyruvate oxidation in spinocerebellar denerations. Ann Neurol 8: 129.

Fidanza A, Audisio M (1982) Vitamins and lipid metabolism. Acta Vitaminol Enzymol 4: 105-114.

Filla A. Manfellotto G, Brescia-Morra V, De Michele G, Palma V, Campanella G (1984) Leukocytes glutamate dehydrogenase in inherited ataxias. Acta Neurol - in press.

Filla A, Postiglione A, Rubba P, Patti L, De Michelle G, Palma V, Brescia-Morra V, Campanella G (1980) Plasma lipoprotein concentration and erythrocyte membrane lipids in patients with Friedreich's ataxia. Acta Neurol (NS) 2: 382-389.

Gibson GE, Jope R, Blass JP (1975) Decreased synthesis of acetylcholine accompanying impaired oxidation of pyruvic acid in rat brain minces. Biochem J 148: 17-23.

Giroux JM, Barbeau A (1972) Erythrokeratodermia with ataxia. Arch Derm 106: 183-188.

Goodman HD, Connolly BM, McLean, W, Resnick M (1980) Taurine transport in epilepsy. Clin Chem 26: 414-419.

Gusella JF, Wexler NS, Conneally PM, Naylor SL, Anderson MA, Tanzi RE, Watkins PC, Ottina K, Wallace MR, Sakaguchi AY, Young AB, Shoulson I, Bonilla E, Martin JB (1983) A polymorphic DNA marker genetically linked to Huntington's disease. Nature 306: 234-238.

Harding AE, Muller DPR, Thomas PK, Willison HJ (1982) Spinocerebellar degeneration secondary to chronic intestinal malabsorption: A Vitamin E deficiency syndrome. Ann Neurol 12: 419-424.

Hewre RL (1968) Study of fatal cases of Friedreich's ataxia. Brit Med J 3: $649-652$.

Hewer RL (1969) The heart in Friedreich's ataxia. Brit Heart J 31: 5-14.

Hughes JT, Brownell B, Hewer RL (1968) The peripheral sensory pathway in Friedreich's ataxia. An examination by light and electron microscopy of the posterior nerve roots, posterior root ganglia, and peripheral sensory nerves in cases of Friedreich's ataxia. Brain 91: 803-818.

Hurley LS, Vokert NE (1965) Pantothenic acid deficiency in guinea pigs during gestation. Biochem Biophys Acta 104: 372-375.

Jabbari B, Schwartz DM, MacNeil DM, Coker SB (1983) Early abnormalities of brainstem auditory evoked potentials in Friedreich's ataxia: evidence of primary brainstem dysfunction. Neurology (Clev.) 33: 1071-1074.
Kark RAP, Blass JP, Engel WK (1974) Pyruvate oxidation in neuromuscular disease - Evidence for a genetic defect in two families with the clinical syndrome of Friedreich's ataxia. Neurology 24: 964-971.

Kark RAP, Blass JP, Spence MA (1977) Physostigmine in familial ataxias. Neurology 27: 70-72.

Kark RAP, Rodriguez-Budelli M (1979a) Pyruvate dehydrogenase deficiency in spinocerebellar degenerations. Neurology 29: 126-131.

Kark RAP, Rodriguez-Budelli M (1979b) Clinical correlations of partial deficiency of lipoamide dehydrogenase. Neurology 29: 1006-1013.

Koyanagi T, Obori H (1965) Effect of pantothenic acid and Vitamin B on the excretion of taurine in the urine of rats. Tohoku J Exp Med 86: 394-396.

Kraus-Ruppert R (1964) Erganzendes zur kenntnis der spino-pontocerebellaren atrophien und zur frage des zellstoffwechsels. Arch Psychiat Nervenkr 205: 409-432.

Launay M, Lapous D, Raulin J (1981) Control of replication by dietary lipids and namely by linoleic acid in liver and adipose tissue of developing rats. Prog Lipid Res 20: 331-338.

Lubozynski MF, Roelofs RI (1975) Friedreich's ataxia: a review of recent literature. South Med J 68: 757-763.

Mahboob S (1975) Effect of pantothenic acid deficiency on microsomal lipids of rat liver. Nutr Metabol 19: 91-95.

Mahboob S, Estes LW (1978) Effect of pantothenic acid deficiency on rat hepatocytes. Nutr Metabl 22: 177-180.

Margalith D, Dunn HG, Carter JE, Wright JM (1984) Friedreich's ataxia with dysautonomia and labile hypertension. Can J Neurol Sci 11: $73-77$.

Marks JD, Berry HK (1962) Increase in urine amino acids associated with pantothenic acid deficiency in the rat. in: (J.T. Holden, ed.), Amino Acid Pools, New York, Elsevier Publ Co., pp. 461-464.

May WE (1984) Nutritional sensory neuronopathy - An emerging new syndrome. Arch Neurol 41: 559-560.

McLeod JG (1970) Electrophysiological and sural nerve biopsy studies in patients with Friedreich's ataxia and Charcot-Marie-Tooth disease. Proc Aust Ass Neurol 7: 89-95.

Muller DPR, Lloyd JK, Wolff OH (1983) Vitamin E and neurological function. The Lancet 1: 225-228.

Nelson JS, Fitch CD, Fischer VW, Broun GO, Chou AC (1981). Progressive neuropathologic lesions in Vitamin E-deficient Rhesus monkeys. J Neuropath Exp Neurol 40: 166-186.

Packman S, Sweetman L, Baker H, Wall S (1981a) The neonatal form of biotin responsive multiple carboxylase deficiency. J Pediatr 99: 418-420.

Packman S, Sweetman L, Yoshimo M, Baker H, Cowan M (198Ib) Biotin responsive multiple carboxylase deficiency of infantile onset. J Pediatr 99: 421-423.

Perry TL, Hansen S, Currier RD, Berry K (1978) Abnormalities in neurotransmitter amino acids in dominantly inherited cerebellar disorders. Adv Neurol 21: 303-314.

Plaitakis A, Berl S, Nicklas WJ, Yahr MD (1980a) Glutamate dehydrogenase deficiency in spinocerebellar degeneration: correlation with adult-onset recessive ataxia. Trans Am Neurol Ass 105: 476-477.

Plaitakis A, Berl S, Yahr MD (1981) Amino acids as putative transmitters: the role of aspartate and glutamate in nervous system dysfunction and degeneration. Excerpta Medica ICS 568: 259-273.

Plaitakis A, Berl S, Yahr MD (1982) Abnormal glutamate metabolism in adult-onset degenerative neurological disorder. Science 216: 193-196.

Plaitakis A, Berl S, Yahr MD (1984) Neurological disorders associated with deficiency of glutamate dehydrogenase. Ann Neurol 15: 144-153.

Plaitakis A, Berl S, Yahr MD (1983) Evidence for mutation of a glutamate dehydrogenase 'isoenzyme' in recessive olivo-ponto-cerebellar atrophy. Ann Neurol 14: 108-109.

Plaitakis A, Nicklas W, Desnick RJ (1980b) Glutamate dehydrogenase deficiency in three patients with spinocerebellar syndrome. Ann Neurol 7: 297-303.

Podolsky S, Pothier A, Krall LP( 1964) Association of diabetes mellitus and Friedreich's ataxia. Arch Int Med 114: 533-537.

Quick AJ (1936) Clinical value of test for hippuric acid in cases of diseases of liver. Arch Int Med 57: 544-560.

Reibel DK, Wyse BW, Berkich DA, Neely JR (1982) Coenzyme A metabolism in pantothenic acid-deficient rats. J Nutr 112: 11441150.

Reibel DK, Wyse BW, Berkich DA, Palko WM, Neely JR (1981) Effects of diabetes and fasting on pantothenic acid metabolism in rats. Am J Physiol 240 (Endocrinol Metab 3) E: 597-601. 
Refsum S.(1946).Heredopathia atactica polyneuritiformis: a familial syndrome not hiterto described. A contribution to the clinical study of the hereditary diseases of the nervous system. Acta Psychiat Scand suppl 38: 1-303.

Robinson N (1966a) Friedreich's ataxia: a histochemical and biochemical study. I. Enzymes of carbohydrate metabolism. Acta Neuropath (Berl) 6: 25-34.

Robinson N (1966b) Friedreich's ataxia: a histochemical and biochemical study. II. Hydrolytic enzymes. Acta Neuropath (Berl) 6: 35-45.

Robinson N (1968) Chemical changes in the spinal cord in Friedreich's ataxia and motor neurone disease. J Neurol Neurosurg Psychiat 31: 330-333.

Robinson N, Curzon G, Theaker P (1965b) Excretion of tryptophan metabolites in Friedreich's ataxia. J Clin Path 18: 797-799.

Robinson N, Phillips BM, Cummings JN (1965b) Serum enzymes in Friedreich's ataxia. Brain 88: 131-136.

Rowland LP (1983) Molecular genetics, pseudogenetics and clinical neurology (The Robert Wartenberg Lecture). Neurology 33: 1179-1 195.

Sander JE, Malamud N, Cowan MJ, Packman S, Amman AJ, Wara DW (1980) Intermittent ataxia and immunodeficiency with multiple carboxylase deficiences: a biotin-responsive disorder. Ann Neurol 8: $544-547$.

Sander JE, Packman S, Townsend JJ (1982) Brain pyruvate carboxylase and the pathophysiology of biotin-dependent disease. Neurology (NY) 32: 878-880.

Smith CM, Cano ML, Potyraj J (1978) The relationship between metabolic state and total Co A content of rat liver and heart. J Nutr 108: 854-862.

Stannton HC, Brenner G, Mayfield ED (1969) Studies on isoproterenolinduced cardiomegaly in rats. Am Heart J 77: 72-80.

Stumpf DA (1982) Friedreich's disease: a metabolic cardiomyopathy. Am Heart J 104: 887-888.

Stumpf DA, Parks JK (1978) Friedreich's ataxia: I. Normal pyruvate dehydrogenase complex activity in platelets. Ann Neurol 4: 366-368.

Stumpf DA, Parks JK (1979) Friedreich's ataxia: Il. Normal kinetics of lipoamide dehydrogenase. Neurology 29: 820-826.

Stumpf DA, Parks JK, Eguren LA, Haas R (1982) Friedreich's ataxia: III. Mitochondrial malic enzyme deficiency. Neurology (NY) 32: 221-227.

Stumpf DA, Parks JK, Parker WD (1983) Friedreich's ataxia: IV. Reduced mitochondrial malic enzyme activity in heterozygotes. Neurology (Clev) 33: 780-783.

Swank RL, Adams RD (1948) Pyridoxine and pantothenic acid deficiency in swine. J Neuropath Exp Neurol 7: 274-286.

Szanto J, Gallyas F (1966) A study of iron metabolism in neuropsychiatric patients. Hallervorden-Spatz disease. Arch Neurol (Chic) 14: 438-442.
Tarr JB, Tamurat T, Stokstad ELR(1981) Availability of Vitamin B and pantothenate in an average American diet in man. Am J Clin Nutr 34: 1328-1337.

Thoene J, Wolf B (1983) Biotinidase deficiency in juvenile multiple carboxylase deficiency. The Lancet 2: 398.

Thorén C (1964) Cardiomyopathy in Friedreich's ataxia with studies of cardiovascular and respiratory function. Acta Paediatr Scand 53, suppl 153: 1-100.

Thurston JH, Hauhart RE, Naccarato EF (1981) Taurine: possible role in osmotic regulation of mammalian heart. Science 214: 1373-1374.

Tsujikawa M, Kimura S (1981) Effect of exposure to cold on pantothenic acid metabolism in rat liver. Tohoku J Exp Med 133:457-460.

Tyrer JH (1975) Friedreich's ataxia. In: (Vinken, PJ and Bruyn GW eds), Handbook of Clinical Neurology, Amsterdam, Elsevier Publ, 21: 319-364.

van Gelder NM (1983) Principles of Compartmentation. In: Lajtha A (ed), Handbook of Neurochemistry, Plenum Publ Corp, vol 2 (2nd edition), pp 183-206.

Walker JL, Chamberlain S, Robinson N (1980) Lipids and lipoproteins in Friedreich's ataxia. J Neurol Neurosurg Psychiat 43: 111-117.

Walsh JH, Wyse BW, Gaurth Hansen R (1981) Pantothenic acid content of 75 processed and cooked foods. J American Dietet Assoc 78: 140-144.

Werlin SL, Harb JM, Swick H, Blank E (1983) Neuromuscular dysfunction and ultrastructural pathology in children with chronic cholestasis and Vitamin E deficiency. Ann Neurol 13: 291-296.

Wiklund L, Toggenburger G, Cuenod M (1982) Aspartate: possible neurotransmitter in cerebellar climbing fibers. Science 216: 78-80.

Wintrobe MM, Follis RH, Alcayaga R, Paulson N, Humphreys S (1943) Pantothenic acid deficiency in swine. Bull Johns Hopkins Hospital 73: 313-341.

Wintrobe MM, Miller HM, Follis RH, Stein HJ, Mushatt C, Humphreys S (1942) Sensory neuron degeneration in pigs. IV. Protection affored by calcium pantothenate and pyridoxine. J Nutr 24: 345-366.

Yamaguchi T, Hayashi K, Mura-Kami H, Ota K, Maruyama S (1982) Glutamate dehydrogenase deficiency in spinocerebellar degeneration. Neurochem Res 7: 627-636.

Yao JK, Dyck PJ (1978) Lipid abnormalities in hereditary neuropathy -Part 2: serum phospholipids. J Neurol Sci 36: 225236.

Yao JK, Dyck PJ (1979) Accumulation of polyunsaturated fatty acids in developing peripheral nerve. Proc Amer Soc Neurochem 12: 214.

Yorek MA, Strom DK, Spector AA (1984) Effect of membranes polyunsaturation on carrier-mediated transport in cultured retinoblastoma cells: alterations in taurine uptake. J Neurochemistry 42 : 254-261. 